Carlos Préndez Saldías

\title{
A una muerta querida
}

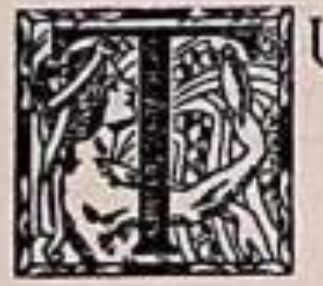

US brazos, los que fueron entraña arrulladora de mi niñez sin madre, ya no pueden ahora estrecharme a tu vida.

Si están quietos y largos bajo la tierra que hace frutos de miel y amargos!

Ya sabes el misterio de la orilla siniestra a que arrima su barca la pobre vida nuestra, y se abrieron tus ojos al horizonte claro de la mañana inmensa.

Yo con mi desamparo y mi sed de infinito, voy pidiendo al destino que retarde el recodo del último camino. Un miedo de morir, grande como este anhelo que me tiene los ojos perdidos en el cielo y en las rutas lejanas, me deja todavía ser un buen hombre alegre con mi melancolia...

No vienes a decirme que llegó la mañana, 
A una muerta querida

ni abres, para que mire su canción, la ventana que da al jardín sonoro.

¡Porque no estás conmigo, el paisaje no asoma en el verso que digol

¡Oh, mi muerla queridal Si la verdad no es ésa deslumbradora y dulce de tu fe, Iqué tristeza cruel y desconsolada será la que tú tienes viendo que Dios te deja con el polvo en las sienes!

Todo lo fui en tu vida. Y estabas en mi abrazo cuando dijo a tu oído la muerte su palabra. Yo, como el solitario que no tiene regazo, temblaré en el silencio cuando la puerta se abra y mire que la ha abierto la mano del acaso.

Si mi niñez lué tuya, no era tu Dios el mío. Se fué tu vida santa cual velero en un río apacible, que sigue la corriente amorosa. IMi muerte desgarrada de negador sombrio será como un naufragio en la noche brumosal 